\title{
Steroid resistant pleural effusion in systemic lupus erythematosus treated with tetracycline pleurodesis
}

\author{
M H GILLEECE, C C EVANS, AND R C BUCKNALL \\ From the Royal Liverpool Hospital, England
}

SUMMARY A 26 year old woman had recurrent unilateral pleural effusions secondary to active systemic lupus erythematosus. The effusions were resistant to conventional treatment with steroids but did not recur after tetracycline pleurodesis.

Respiratory involvement in systemic lupus erythematosus (SLE) is relatively common. Pleural effusions have been recorded in up to $44 \%$ of patients with SLE. ${ }^{1}$ The effusion is usually a yellow exudate containing high concentrations of immunoglobulins and low concentrations of complement. Immune complexes have been demonstrated in the effusions and in pleural capillary walls. ${ }^{2}{ }^{3}$ It has been proposed that immune complexes have a major role in the pathogenesis of pleural effusions in SLE, perhaps by increasing pleural capillary permeability. ${ }^{4}$ Classically, the effusions respond rapidly to steroid treatment. ${ }^{56}$

This report describes a patient with a recurrent unilateral pleural effusion secondary to active SLE. Steroids did not produce resolution or prevent reaccumulation after aspiration of the effusion. Tetracycline pleurodesis successfully prevented recurrence of the effusion.

\section{Case report}

A 26 year old previously well woman presented in July 1984 with a three month history of painful swollen peripheral joints and an erythematous papular rash confined to light exposed areas.

She had a normocytic normochromic anaemia (haemoglobin $101 \mathrm{~g} / \mathrm{l}$ ). Serum complement components $\mathrm{C} 3$ and $\mathrm{C} 4$ were reduced to $650 \mathrm{mg} / \mathrm{l}$ and $90 \mathrm{mg} / \mathrm{l}$ respectively (normal range (NR) $700-1700 \mathrm{mg} / \mathrm{l}$ and $150-550 \mathrm{mg} / \mathrm{l}$ ). Homogeneous antinuclear antibodies at a level of $400 \mathrm{IU} / \mathrm{ml}$ were associated with increased DNA binding of $24 \%$

Accepted for publication 20 May 1988.

Correspondence to Dr R C Bucknall, Royal Liverpool Hospital, Prescot Street, Liverpool L7 8XP. (normal range less than $10 \%$, using S1 nuclease treated $\left.\left[{ }^{14} \mathrm{C}\right] \mathrm{DNA}\right) .{ }^{7}$ Serum immunoglobulins were raised: IgG $24.4 \mathrm{~g} / 1$ (NR 5.00-14.00 g/1), IgA 7.68 g/l (NR $1.00-4.00 \mathrm{~g} / \mathrm{l}$ ), and IgM $2.13 \mathrm{~g} / \mathrm{l}$ (NR 0.05 $2.00 \mathrm{~g} / \mathrm{l})$. Skin biopsy showed epidermal focal parakeratosis and dermal necrosis. Pulmonary function tests revealed a restrictive defect. All other tests, including renal function, were unremarkable.

Systemic lupus erythematosus was diagnosed. Her symptoms responded quickly to aspirin, indomethacin, and topical betamethasone. The patient then remained well until October 1984 when she presented after seven days of left sided pleuritic pain and dyspnoea and three days of vomiting, colicky abdominal pain, and rectal passage of fresh blood mixed with faeces. She was pyrexial at $39^{\circ} \mathrm{C}$ with a left sided pleural effusion, confirmed radiologically, and peritonism. Abdominal radiography, serum amylase, and endoscopy of upper and lower gastrointestinal tract showed no more than a single haemorrhoid. Serum C3 was $350 \mathrm{mg} / 1$ and C4 $110 \mathrm{mg} / \mathrm{l}$. Full blood count and microbiology screen were unremarkable. Pleural aspirate produced a sterile exudate (protein $46 \mathrm{~g} / \mathrm{l}$ ). A diagnosis of mesenteric vasculitis associated with active SLE was made, and treatment with intravenous hydrocortisone and methylprednisolone was started. There was a rapid response within 48 hours.

Steroids were gradually reduced to $10 \mathrm{mg}$ prednisolone daily. The patient remained well until August 1985 when she developed a large left sided pleural effusion causing mediastinal shift. Serum C3 was $230 \mathrm{mg} / \mathrm{l}$ and C4 $40 \mathrm{mg} / \mathrm{l}$. Sterile exudate $(3.21$ containing protein $45-50 \mathrm{~g} / \mathrm{l})$ was aspirated. Prednisolone dosage was doubled to $20 \mathrm{mg}$ daily. By September 1985 the residual effusion had increased 
in size despite an increase in prednisolone to $80 \mathrm{mg}$ daily. A further 5.451 of sterile exudate was aspirated.

Steroids had clearly failed to prevent or to aid resolution of the effusion. On 30 October 1985, therefore, the effusion was drained to dryness via an intercostal drain and low grade suction after which tetracycline $500 \mathrm{mg}$ was placed in the pleural space. The patient has had no further pleural effusions despite an exacerbation affecting her joints and skin, which responded to prednisolone. She is currently well but cannot manage on a dose of prednisolone less than $10 \mathrm{mg}$ daily.

\section{Discussion}

This patient with SLE had recurrent unilateral sterile exudative effusions. The timing of her effusions coincided with exacerbations of her SLE manifested by worsening symptoms and hypocomplementaemia. Usually, such effusions respond rapidly to glucocorticoid treatment. In this patient, however, the effusion was never eliminated by steroid treatment, and high doses of prednisolone did not prevent reaccumulation after aspiration of the effusion.

Immunosuppressive treatment, such as azathioprine, is used successfully in the treatment of SLE. In this case of a young fertile woman whose SLE was otherwise controlled by steroids pleurodesis was the preferred option. There is no evidence to suggest that azathioprine or other cytotoxic drugs will succeed where steroids have failed. Tetracycline has been widely used in the management of recurrent pleural effusions of different aetiology.
This is the second reported case of pleural effusion in SLE unresponsive to steroid treatment. The only other report described a 31 year old black man whose SLE presented as renal disease. ${ }^{8}$ His effusions were on some occasions a transudate. In the present case the effusions were consistently an exudate and there were no manifestations of renal disease.

Thus pleural effusions in SLE should no longer be assumed to be always responsive to steroids, and pleurodesis should be considered early in the management of recurrent large pleural effusions.

\section{References}

1 Alarcon-Segovia D, Alarcon D G. Pleuro-pulmonary manifestations of systemic lupus erythematosus. Diseases of the Chest 1961; 39: 7-17.

2 Butman S, Espinoza L R, DelCarpio K, Osterland K. Rheumatoid pericarditis. Rapid deterioration with evidence of local vasculitis. JAMA 1977; 238: 2394-6.

3 Schoket A L, Lain D, Kohler P F, Steigerwald J. Immune complex vasculitis as a cause of ascites and pleural effusions in systemic lupus erythematosus. J Rheumatol 1978; 5: 33-8.

4 Andrews B S, Arora N S, Shadforth M F, Goldberg S K. The role of immune complexes in the pathogenesis of pleural effusions. Annual Review of Respiratory Diseases 1981; 124: 115-20.

5 Hunder G G, McDuffie F C, Hepper N G G. Pleural fluid io systemic lupus erythematosus and rheumatoid arthritis. An Intern Med 1972; 76: 357-62.

6 Winslow W A, Ploss L N, Loitman B. Pleuritis in systemic lupw erythematosus: its importance as an early manifestation in diagnosis. Ann Intern Med 1958; 49: 70-88.

7 Barnes R M R, Kenton P. Analysis of serum binding to DNA and other ligands in systemic lupus erythematosus. Immunol Lett 1985; 10: 99-102.

8 Kaine J L. Refractory massive pleural effusion in systemic lupus erythematosus treated with talc poudrage. Ann Rheum Dis 1985; 44: 61-4. 